\title{
Dobutamine Hydrochloride
}

National Cancer Institute

\section{Source}

National Cancer Institute. Dobutamine Hydrochloride. NCI Thesaurus. Code C28997.

The hydrochloride salt form of dobutamine, a synthetic catecholamine with direct inotropic activity. Dobutamine hydrochloride, mimics the effects of dopamine and stimulates beta- 1 adrenergic receptors located in the myocardium. This leads to an increase in heart rate and force and results in an increase in cardiac output. 